\title{
The Biological Survey of Canada turns 40: a special issue for a special occasion
}

\author{
Donna J. Giberson, ${ }^{1}$ Héctor A. Cárcamo
}

It is fitting to celebrate the 40th anniversary of the Biological Survey of Canada (BSC) with a special issue published in the journal of the Entomological Society of Canada. The principles leading to the success of the BSC stemmed from discussions held in the early 1970s by visionary members of this society. "A biological survey of the insects of Canada" (Downes 1974) outlined the concept for the BSC, one of advancing knowledge on the arthropod fauna of Canada through grass-root collaborative efforts without actually forming a separate complex and expensive institution. The first paper in this special issue, by Danks (2017), provides a summary and assessment of how this model has worked over the 40-year history of the BSC, and points to the substantial body of literature that has resulted from these efforts. He concludes that the BSC is a model demonstrating the power of scientific cooperation when "bottom-up" mechanisms prevail over "top-down" approaches. However, technological and analytical changes during the 40-year history of the BSC have meant that how we obtain and distribute our biodiversity data have also changed. Therefore, the history of the BSC is also, to some extent, a history of arthropod faunistic studies in Canada.

Floate et al. (2017) illustrate this in their retrospective paper on the BSC's long-running "Arthropods of Canadian Grasslands" project. They trace the project from the original choice of grassland ecosystems for study due to rapid habitat loss and lack of faunal information, through a multi-year process of identifying needs and gaps, to its milestone achievement of publishing a four-volume series summarising current knowledge on the geography, climate, ecology, and biodiversity of these fragile ecoregions. They are then able to update the state of biodiversity information for this habitat, along with an assessment of how the project has been received by the broader scientific community, thanks to advances in bibliographic databases that have been concurrent with advances in faunistic studies.

There are many examples of how technological advances over the 40-year history of the BSC have influenced how we now collect and use biodiversity information. For example, Vankosky et al. (2017) use the grassland ecosystem to illustrate how, once we have information on faunal patterns in a region, we can take advantage of new analytical methods to ask bigger questions. They provide an extensive review of how agricultural transformation of the Canadian grasslands has affected arthropod biodiversity, then use landscape ecology principles to demonstrate major knowledge gaps in Canadian grasslands. A novel feature of this article is the inclusion of biocontrol agents as inputs in rangeland and cultivated agroecosystems, and a summary of the scant knowledge on their ecological impacts on native biodiversity.

Another major technological change over the history of the BSC has been more basic; the addition of molecular (DNA-based barcoding) characters to our taxonomic toolboxes when determining species patterns for regional faunal assessments. The contribution by Sheffield et al. (2017) provides an example of how barcoding can add to faunistic knowledge in the bees in a region and identify knowledge gaps for specific groups

D.J. Giberson, ${ }^{\mathbf{1}}$ Department of Biology, University of Prince Edward Island, 550 University Avenue, Charlottetown, Prince Edward Island, C1A 4P3, Canada

H.A. Cárcamo, Agriculture and Agri-Food Canada, Lethbridge Research and Development Centre, 5403-1 ${ }^{\text {st }}$ Avenue South, Lethbridge, Alberta, T1J 4B1, Canada

${ }^{1}$ Corresponding author (e-mail: giberson@ upei.ca). doi: $10.4039 /$ tce. 2017.53 
or locations. They summarise the state of knowledge for each bee family, noting the continued need for morphological and ecological study as well as molecular methods to address these gaps. Giberson and Burian (2017) continue the theme of making use of methodological advances, as they ask how and if old species lists can inform our current knowledge of faunistic patterns. Using northern species of Ephemeroptera as an example, they look at how updated species revisions and improved access to taxonomic information can provide the tools to update species lists, when samples have been archived in accessible collections.

We finish this series with an article by Acorn (2017) on the growing importance of citizen science projects to assess biodiversity knowledge. The field of entomology has long been associated with amateurs collecting and identifying insects, but it is only recently that there have been formal efforts to organise citizens in insect faunistic studies. The author reviews the broad definition of citizen science, then highlights several examples, including one of the most successful Canadian contributions to the North American databasing projects: e-butterfly. In the last section of this article, Acorn (2017) provides an insightful discussion of the characteristics of successful citizen science projects in Canada and answers the key question "Has the idea as a whole been successful, and in particular, has it been successful in Canada?"

That question could be applied equally to the BSC, and their model of collaborative science to address biodiversity issues in the country. These papers give a taste of the success of the organisation, showing not only how their efforts have driven biodiversity data collection for Canadian regions and taxonomic groups, but also how those data have subsequently been used to address broader ecological and taxonomic questions. The BSC can continue to build on their 40-year history to address these questions through the years to come.

Dedication: As we were in the final stages of preparations for this special issue, Terry Wheeler, a long-time member of the Biological Survey of Canada Scientific Committee and Board, passed away. Terry was involved with the BSC for 20 years, half of its official history, and contributed greatly to the BSC and its projects. We dedicate this issue to Terry, in memory of his contributions to the BSC and to faunistic studies in Canada.

\section{References}

Acorn, J.H. 2017. Entomological citizen science in Canada. The Canadian Entomologist, 149: 774-785.

Danks, H.V. 2017. Benefits and principles of the Biological Survey of Canada: a model for scientific cooperation. The Canadian Entomologist, 149: 693-701.

Downes, J.A. 1974. A biological survey of the insects of Canada. Bulletin of the Entomological Society of Canada, 6 (Supplement): 1-16.

Floate, K.D., Shorthouse, J.D., Giberson, D.J., and Cárcamo, H.A. 2017. Arthropods of Canadian grasslands: a retrospective of a 40 -year project of the Biological Survey of Canada. The Canadian Entomologist, 149: 702-717.

Giberson, D.J. and Burian, S.K. 2017. How valid are old species lists? How archived samples can be used to update Ephemeroptera biodiversity information for northern Canada. The Canadian Entomologist, 149: $755-773$.

Sheffield, C.S., Heron, J., Gibbs, J., Onuferko, T.M., Oram, R., Best, L., et al. 2017. Contribution of DNA barcoding to the study of the bees (Hymenoptera: Apoidea) of Canada: progress to date. The Canadian Entomologist, 149: 736-754.

Vankosky, M.A., Cárcamo, H.A., Catton, H.A., Costamagna, A.C., and De Clerck-Floate, R. 2017. Impacts of the agricultural transformation of the Canadian Prairies on grassland arthropods. The Canadian Entomologist, 149: 718-735. 